\title{
IMPLEMENTING LEARNING MODEL BASED ON INTERACTIVE LEARNING COMMUNITY FOR EFL STUDENTS OF MUHAMMADIYAH UNIVERSITY
}

\author{
Eny Syatriana ${ }^{1}$ \\ enysatriana@unismuh.ac.id \\ Geminastiti Sakkir ${ }^{2}$ \\ hj.geminastitisakkir@yahoo.com
}
${ }^{1}$ Senior Lecturer, English Department of Education and Training Faculty, Muhammadiyah, University of Makassar, Indonesia
${ }^{2}$ Lecturer, English Education Department, Universitas Negeri Makassar, Indonesia

\begin{abstract}
The main objective of this study was to investigate speaking ability of Muhammadiyah University students. It is the most intense language ability which is used in communicating with others. Speaking material plays an important role in various language productions. Such conversation can be in the form of discussion, speech, debate, dialogue, storytelling, retelling. The speakers use oral language to express their desires, feelings, thoughts with others, so that people can understand what they want, but there are still many misunderstandings that can affect the students' mastery of accuracy, fluency, flexibility and comprehensibility. A total number of 35 students in third semester studens have been involved in this study, who are sampled by using total sampling technique. From this study, it was found that leaning community can motivate students to speak up effectivelly. The students' competence in speaking skills of Unismuh Makassar are not fully in line with curriculum expectations in terms of the critical thinking. Therefore, to achieve the goal of teaching speaking skills, lecturer are required to use the methods that can encourage the leaners' interest and motivate more until their speaking skills can be improved. The key words of the learning community method are learning and sharing experiences with others, working with others to create better learning among members of groups enhance the awareness, confidance, and sharing experience. The finding of this study can improve the speaking abiity from learning community stages futhermore it has been answer the researh question in terms of the application of Learning Community can attract studets participation in oral skill.
\end{abstract}

Keyword : Learning model, learning community, speaking, development

\section{INTRODUCTION}

The aim of teaching speaking in English is to train students to be able to explore meaningful and contextual communications in English as in real life. In the learning process of teaching that applies learning community methods, it focuses on speaking and sharing experiences with others, working with others can create better learning. The Learning community method treats students by having assignments 
in the form of communication. The learning is oriented towards the goals to achieve, it is the communicative objectives. In other words, more attention is given directly towards understanding and delivering meaning. To make the teaching-learning process more affective, good methods must be used by a lecturer. By this, the ability to use the language is to communicate as in real life. Communicative learning is expected that students can be more creative to develop their skills in speaking. The students' competence to speak will be seen from the use of technology on the global curriculum.

A reality was shown, based on the reserarcher's experience to observe the teaching and learning in the classroom, most students were not seen to learn actively, when the lecturer was teaching them English. During the learning process, English lecturers have not yet empowered all of their potentials, therefore most of the students are not able to achieve their individual basic competencies which is needed to participate in intermediate level of English. They have not maximally learned the communication level in English (Melvin, 2006). Student can learn only reading, memorizing the words, writing, and English rules (Sakkir, 2016). Furthermore, the innovative ideas is still on the level of memory, they have not been able to use English effectively in daily communication. In particular, the researcher formulated research questions as follows: How can LC are applied in teaching speaking in English? What were the students' responses towards the implementation of LC in learning speaking? Harmer (2001) says that speaking or communicating is a sharing ideas or information between two or more person who involve in it. Furthermore Speight also argues that speaking is a form of communication that involves two or more people with certain topics. This means that the speaking activity engages the participants to interacts each other.Then, Johnson (2002) said that speaking is an activity to express ideas, opinions, feelings by using language or speak to themselves. Nunan (1997) said that speaking is a process of communication in expressing ideas, thoughts, and other ways in formal or informal situation. In this context, it is emphasized that the most important thing in speaking (speaking) is the arrival of information and language models from speakers to listeners (listeners) and listeners to provide feedback when needed. The research behind helicopters was by some fact low-skilled English-speaking students at the teacher level and method of learning English-speaking English. For this basic background, it is necessary to apply the English language learning model that can improve student skills in speaking English. This study will implement learning community in order to improve the speaking ability. And to know the interest of the students. The English speaking skills of Makassar Unismuh students are still low (Syatriana, 2011) indicating the need for attention on the handling of good English learning in tertiary institutions. Students who have good speaking skills can present their final assignments in the form of a thesis, this skill plays an important role in student presentation.

Atkinson (1985) divides four basic competencies which must be mastered by language learners, namely reading, listening / listening, speaking, and writing. Writing and speaking are outputs while reading and listening are inputs that must be trained in order to produce adequate output. In learning languages, there are two main skills that need to be mastered, namely: (1) receptive skills and productive skills. Receptive skills consist of: listening and reading skills, (2) productive skills consisting of: speaking skills (speaking) and writing skills (writing). The following is an explanation of skill. Listening means listening to something to get an understanding of what is heard. As with reading, there are some important aspects or skills that need to be considered in listening, namely: (1) understanding the points of thoughts conveyed by the speaker, (2) understanding the details or details that support the points of thought expressed by the speaker. A good listener uses note taking skills while listening to a description. If we pay attention to the activities that we carry out everyday, then we find that the role of listening is 
estimated at $40 \%$ of the time we spend communicating as a listenerSpeaking is a skill in conveying information, ideas or concepts to the listener. So that the commentary can be easily understood by the listener, the speaker usually uses certain procedures in conveying his ideas. The speaker always tries to make the information conveyed easily understood by the listeners.

There are several important things that must be considered by English speakers so that the message delivered can be understood by the listeners properly, namely: (1) The speaker's pronunciation must be good, clear and accurate. Language mastery is not only determined by the extent or extent of mastery of the grammar but also how accurate / clear the speaker is saying words, phrases, or sentence by sentence in the speech information.(2). State the main thoughts in complete sentences. The mind is the most important information that the speaker wants to convey.(3).Developing ideas by giving explanations, descriptions or examples.(4). Using sentences that are easily understood by the listener. The sentences to be used are adjusted to the level of student ability. Use the right intonation of the sentence and the right body movements (body movement or eye contact) to help the listener's understanding. Reading is one of the four important language skills to be mastered by anyone who wants to improve science. Reading is an appropriate means to promote lifelong learning. Teaching students to read means giving them the skills to gain or increase their knowledge so that they can become students who are full of broad insights. The meaning of reading, reading is a process of language and communication, which is a process that gives readers the opportunity to make contact and communication with various ideas (Dechant, 1982). Therefore, reading always involves interaction between the writer and the reader. Reading is an act of the communication process that starts from the writer's mind expressed through symbols on paper. Without the reader, communication through writing on paper is not possible. Writing that can not be separated from human life is a form of communication where someone can express ideas, feelings, or knowledge. Writing learning is an important activity of the entire learning process experienced by learners. As in reading skills, learners in writing also need to think about the main ideas (main ideas) to be conveyed (Sakkir, G \& Dollah, S, 2019), how the supporting points of thought (supporting details) are formulated, and how details are expressed in supporting these points in conveying messages or information. In general, the components of the writing mechanism consist of: content, organization, grammar, vocabulary, and writing mechanic.

The purpose of this study will implement the result of need analysis and field characteristics related to the development of speaking learning models, which include: lecture learnign enviroenment descriptions in the previous semester by determining the related concepts that can be made as a matter of course in improving the learning process so that the ability to speak up deal with high motivation in speaking, can determine the related concepts that can be made as a matter of course in improving the learning process, is high in speaking skills. Furthermore, the model design of speaking is followed by an assessment of the validity of the contents of model before implemented in the learning process.

The ability to communicate in the learning process of English is not only focused on one skill, but is interconnected or in other words integrated with other skills (Listening, Speaking, Reading and Writing) in the mastery of learning interests and motivation to produce effective and efficient speaking skills. Previous research researchers have produced a learning model Writing Learning Based Approach to Reading Through the Reflection Strategy, Students of the Department of English Education Unismuh In Makassar (2015) Where reflective learning deals with brain and body functions such as higher-order thinking and problem solving. According to Perkins (In Dharma, 2007) the reflective system allows us to 
become whatever we can if reflective intelligence is cultivated and seriously developed. In a dissertation study (Doctoral Grant) in 2014 researchers conducted a development study entitled Designing English Instructional Materials for EFL Artistic High School Students Based on the Educational Unit Level Curriculum. In 2011 researchers also conducted a development study entitled Development of competency-based English learning models with the application of PPP. This research uses a research and development approach, Research and Development (R \& D) whose development activities are based on English education technology supported by several approaches, types of research and evaluation. Field Analysis and problem identification Survey of Needs for Speaking Teaching Material Models and Limited Empirical Trials. This stage three types of activities will be carried out, namely:Conceptual analysis, which examines several concepts in learning English, such as basic English skills (listening, speaking, reading, and writing) as well as related concepts that affect English learning through library research. Survey of needs and characteristics of the field, that is to understand the needs and characteristics of the field in the framework of the preparation of learning models in speaking subjects through quantitative and qualitative approaches.

\section{LITERATURE REVIEW}

\section{Learning Community}

Learning Community is related to learning through community services, ICT, and other learning communities (Louse Stoll, Ray Bolam, Agnes McMahon, Mike Wallace, and Sally Thomas, 2006) Learning community is used to describe a combination that can be thought of individuals who are interested in the field of education, and it is strongly recommended that collaboration between lecturers and students occur and alumni ties can be increased involvement through the learning community. Alumni can update their knowledge and skills or can share their experiences in the workforce with their alma mater. To be able to realize this, the learning community must be built to answer the problem of education, strengthening competencies.

Learning community can occur if between students and lecturers have an effective and communicative interaction. A significant learning process if carried out in learning groups, both which allows more knowledge and skills to be acquired. Learning community can occur if learning outcomes are obtained from collaboration with others. This means that learning outcomes can be obtained by sharing among friends, between groups and between those who know to those who don't know, both inside and outside the classroom. Basically, the learning community contains the following: 1) There is a learning group that communicates for various ideas and experiences . 2) There is cooperation in solving problems. 3) In general the results of group work are better than individual work. 4) There is a sense of group responsibility, all members in the group have the same responsibilities. 5) Efforts to build learning motivation for children who have not been able to be held. 6) Creating situations and conditions that allow a child to learn with other children. 7) There is responsibility and cooperation between group members to give and receive one another. 8) There are teachers who guide the learning process in groups. 9) There must be two-way and multi-way communication. 10) There is a will to accept better opinions. 11) There is a willingness to respect the opinions of others. 12) There is no one truth. Learning 
community learning is divided into the following stages. Basic Concept of Learning Strategy for Contextual Teaching and Learning. Contextual Teaching and Learning is a conception that helps lecturers associate the subject matter content with real-world conditions. It also motivates students to connect the knowledge gained and its application in the lives of students as family members, as citizens and as workers. At present many schools in the United States are adopting LC principles. Actually the concept of contextual learning is not a new concept. This concept was first introduced in 1916 by John Dewey, who presented the curriculum and teaching methodology very closely related to students' interests and experiences. According to Johnson stated: "The LC system is an educational process that aims to help students see the meaning in academic material that they learn by connecting academic subjects with the context in their daily lives.

Furthermore, a similar opinion was followed by R.Garrison, T. Anderson(2007). The last three experts stated that the learning program is not just a series of learning units. For learning to be effective, lecturers must explain and have the same views on some basic concepts such as the role of lecturers, the nature of teaching and learning, as well as the mission of universities and in society. Some experts put forward a definition of the CL learning method. According to Sanjaya. LC is a teaching and learning strategy that emphasizes the process of full student involvement to be able to find the material being studied and relate it to real life situations. Thus English learning can be said to be effective if the learning objectives (Basic Competence and Competency Standards) have also been achieved well. Meaningful learning is intended so that the effectiveness of learning is achieved, because with meaningful learning it is very possible the transfer of learning through understanding. Meaningful learning through LC will be more directed if it has clear learning procedures or conceptual frameworks. The conceptual framework of learning describes a systematic procedure in organizing learning experiences to achieve certain learning goals, known as models, so that the learning process becomes directed, then the learning community learning model is a learning model that can increase student activity. This learning model serves as a guideline for learning designers in planning and implementing learning activities, so that learning activities are truly aimed activities that are systematically organized.

\section{METHOD}

The research design of this study takes the form of the quantitative research approach. This research applied total sampling to determine the population samples. 35 students of third semester students in Muhammadiyah University had been randomly selected as the samples of the study. This study uses pre experiemntal design, to implement the learning community stages in six times meeting, evaluation was conducted by an expert to see the effectiveness.

Survey the needs and characteristics of the field, to understand the needs and characteristics of the field for preparing the learning community in the course of speaking subject. through quantitative and qualitative approaches. Implementing learning community in this study through Speaking activity as lecturers selected as in each class are given an understanding of the content and procedures or steps in using a speaking learning model based on the learning community approach. During the period of application of the Model in the limited trial, the research team held discussions to discuss the problems encountered and how to overcome them, suggestions for improvement, and other comments to improve the model and the learning process. 


\section{RESULTS AND DISCUSSIONS}

Students Achievement in Pretest and Posttest in Terms of Accuracy, Fluency and Comprehensibility. The comprehensibility in posttest was higher than the score in pretest. It means that there was significant difference between pretest without treatment and posttest after treatment through learning community. The questionnaire is designed to find out the students' attitude toward their English before and after the implementation of LC. Then the result as in the following: While the rate percentage and frequency of the students' pre-test result in speaking comprehensibility before having treatment through discussion method, there were $5(25 \%)$ students' got poor. 10(50\%) students' got 'average'. $2(10 \%)$ students got 'good' score. 3(15\%) students got 'very good' score and there was no students got very poor score $0(0 \%)$. The data above showed that most students stated in two levels. The data showed that most of the students stated in two levels. There were 3 students got very good. There were 2 students got good, there were 10 students got average and 5 students got poor. After they got treatments the students achievement in speaking were good. It was supported by the rate of percentage of the students' post-test in fluency, where there were 3(15\%) students got "very good" score, $12(60 \%)$ the students got "good" score, $5(25 \%)$ the students got "average" score, there was no students got "very poor" and "poor" score. Both of them got $0 \%$. Based on the data, the researcher concluded most students were in good level. There were 10 numbers of students of student frequencies. The rate percentage and frequency of the students' post-test result in speaking comprehensibility after having treatment through LC method, there were $3(15 \%)$ students got 'very good' score, $12(60 \%)$ the students got 'good' score, $5(25 \%)$ the students got 'average' score, and there was no students got 'poor' and 'very poor' score. The result of the pretest of English learning model indicates that the mean score of 35 students took the test is 79.47 and posttest is 84.10. This indicates that the score is increased after applyingLearning Community, to sum up tah learning Community was an effective way for teaching English in improving speaking especially for the students. It was demonstrated by seeing significant difference between pre-test and post-test materials, as indicated:

Table1: Test Statistics Result of Implementing learning Community

\begin{tabular}{rcc}
\hline & Mean & Std.Deviation \\
\hline Pair 1 PRE TEST & 79.47 & 1.794 \\
POST TEST & 84.10 & 1.920 \\
\hline
\end{tabular}

Table 1 shows the learning Community score of the students pre-test and post-test on the speaking. It could be seen that there were 15 students got score increased, 5 students got score unchanged and no student had low score. It means that $75 \%$ the students got improvement of their score, $25 \%$ students did not get improvement and $0 \%$ students got lower-score. Based on the description above, it could be concluded that the achievement of the students' speaking ability through Learning in post-test were higher than the result of the rate percentage of the students' pre-test. The students result in pre-test and post-test of the students' speaking achievement could be showed in the students' mean score of both pre-test and post-test. The students mean score of fluency in pre-test was 3,8 and the students' mean score 
of comprehensibility was 3,15 . The total students' mean score in pre-test was 79,47 . In post test, the students' mean score of fluency was 3,8 and the students mean score of comprehensibility was 3,9 the total students' mean score in post test was 84,10 . The difference was seen after comparing the value of $t$ test and t-table. This meant that there was significant difference result of the test after teaching and learning process through Learning Community. The result of questionnaires design, based on the question given related to lerning community that students believe, is helped them to improve their communication skill in English with the help of error correction by the lecturer, by study interesting subject and opinion sharing.

According to the findings, After applying learning community strategy it is indicating that speaking tasks which the participants studied in the classroom helped them to increase their competence in communication skills in English because they say the lecturer helped them to correct their mistakes in the learning process. However, some of them stated that these tasks should be implemented more in the classroom environment, and the topics should be interesting enough for the active participation. Throughout the learning process, the students were generally motivated for the listening and speaking tasks given by the lecturer. Students mostly worked in pairs and as a group. During the course steps, the learners helped each other and engaged with the activities. Meanwhile, motivation is one of the significant determination speak up. In this case the researcher was a guider and a facilitator in the classroom environment. Therefore, this helped the students to feel relaxed and comfortable throughout the process. Based on the results of this study, in particular the reflections and analysis of the questionnaires, it can be concluded that LC was able to improve the performance of the students in speaking English. The method used made the lessons more interesting and it is highly desirable for an English teacher to make the lessons more interesting.

As teachers, must be creative in designing and preparing the teaching-learning processes. A teacher should choose an appropriate method, according to the study topic.

\section{CONCLUSIONS, IMPLICATION, AND SUGGESTIONS}

This study focused on the result of implementing learning community among students of the third semester student of Muhammadiyah University. It was found that excessive topic in learning community usage could occur in students as there was significance difference in of stages in students experiencing communication through group discussion. The result suggested of the study was to analyze the use of learning community to improve commprehensibity, accuracy and develop speaking abilities through stages of learning community, to sum up learning Community was an effective way for teaching English in improving speaking especially for the students. It was demonstrated by seeing significant difference between pre-test and post-test. The researcher further come up that other lecturer should not only focus on teaching reading and grammar, but they need to pay more attention to techniques in teaching speaking by explore more various techniques in teaching speaking. Meanwhile, using LC, lecturer should make sure that the activities are related to the content of the materials being taught. Based on the experience of this researcher, LC has been proven to be a productive startegies. 


\section{REFERENCES}

Atkinson, J.S (2005) Learning and Teaching: reflection and reflective practice. Accessed January, 30. 2012 from www.learningandteaching.info/learning/reflecti.htm

Cox, K. E. \& Guthrie, J.T. (2001). Motivational and cognitive contributions to students' amount of reading. Contemporary Educational Psychology, vol. 26, 116-131.

Gagne, R. M. (1985). The condition of learning. (2nd ed.). NY: Holt Rinehart \& Winston.

Harmer, J. (2001). The Practice of English Language Teaching. London: Longman

Johnson, E. B. (2002). Contextual Teaching and Learning, What It Is and Why It Is Here to Stay. Thousand Oaks, CA: Corwin Press.

Perkins, D. N., \& Unger, C. 1999. Teaching and learning for understanding. Dalam Reigeluth, C. M. (Ed.): Instructioal-design theories and models: A new paradigm of instructiontheory, Volume II. New Jersey: Lawrence Erlboum Associates, Publisher.

Sakkir, G. (2016, December). Interest and Writing Skill of the University Students on Using Social Media-Facebook in Writing Class (STKIP Muhammadiyah Rappang, Indonesia). In Asian EFL Journal (Second Language Acquisition-Academic Research) TESOL Indonesia International Conference Edition (Vol. 2, pp. 178-188).

Sakkir, G. (2018). Writing: Beginner. Deepublish. https://books.google.co.id/books?id=2FIVDwAAQBAJ\&printsec=frontcover\&hl=id\#v=onepage $\underline{\& q \& \mathrm{f}=\text { false }}$

Sakkir, G., \& Dollah, S. (2019). Measuring students'writing skills using Facebook group application in EFL context. International Journal of Humanities and Innovation (IJHI), 2(3), 69-72. https://doi.org/10.33750/ijhi.v2i3.43.

Sakkir, G., \& Dollah, S. (2019). FACEBOOK-BASED WRITING INSTRUCTIONAL MATERIAL IN ENGLISH CLASS: LECTURERS'PERCEPTION. SELTICS, 2(2), 76-83.

Sakkir, G., Rahman, Q., \& Salija, K. (2016). Students' Perception on Social Media in Writing Class at STKIP Muhammadiyah Rappang, Indonesia. International Journal of English Linguistics, 6(3), 170-175. doi: 10.5539/ijel.v6n3p170. URL: http://dx.doi.org/10.5539/ijel.v6n3p170.

Syatriana E (2013) A model of creating instructional materials based on the school curriculum for Indonesian secondary school. Journal of Education and Practice, ISSN 222-1735 (paper), ISSN 2222-288X (ONLINE), Vol 4 No 20.

Syatriana E. (2011) Developing a model of teaching of reading comprehension. Makassar.

Tebow, Fall Melinda. 2008. "Reflective Learning in Adult Education". Dalam Artikel [online]. Tersedia: http://adulteducation.wikibook.us/index. php?title=Reflective LearninginAdult_Education. 